\title{
Communication at School - a Threat or an Opportunity for Students' Communicative Competencies? Searching for Answers
}

\section{KEY WORDS}

school-aged child, teacher-student communication, communication at school

\begin{abstract}
Kuszak Kinga, Communication at School - a Threat or an Opportunity for Students' Communicative Competencies? Searching for Answers. Kultura - Społeczeństwo - Edukacja nr 2(10) 2016, Poznań 2016, pp. 69-83, Adam Mickiewicz University Press. ISSN 2300-0422. DOI 10.14746/kse.2016.10.6.

The article tackles the issue of communication in school environment. The first part discusses communication as a dialogue between its participants, who shape its course together, taking turns and forming adjacency pairs. The author moves on to focus on the distinctive features of teacher-student communication. She lists and analyses its following traits: lack of students' opportunity to contribute to the creation of the dialogue, a high level of formality, asymmetry of rights and privileges available to the participants of the communication process, prevalence of a monologue of meanings over a dialogue and negotiation of meanings. The article concludes with proposals for educational practice.
\end{abstract}

\section{Introduction - communication as dialogue}

Since the concept of communication is ambiguous, I will start my article from clarifying the area of further reflection. For the purposes of this paper, I understand communication as a process of direct exchange of information, thoughts and feelings (both through speech and non-verbal elements, such as gestures, facial expressions, vocalisation, etc.) between the involved subjects (each of which takes turns assuming the role of message sender and recipient, making it a two-way communication involving two subjects). This process occurs in a specific context (social, cultural, linguistic, etc.), and the participants' task is to create feedback and attempt to reach an agreement by referring to strategies which 
enable them to mutually understand each other's perspective. Viewed this way, communication is outlined by the framework of a conversation and occurs in several stages, starting from the opening phase - where the participants' aim is to draw attention to themselves and mutually identify each other. As Z. Nęcki points out, "the opening phase may be considered a practical implementation of two interpersonal moves: an invitation to talk and an answer confirming the receipt of the invitation" (Nęcki, 2000: 145). The topic-posing phase is a sequence of taking turns and consists of utterances related to the first tackled topic. The closing phase usually comprises the following elements: completion of the main topics of conversation and expression of "closing" topics and utterances; the final exchange of greetings.

An important element of the process of communication perceived this way is the possibility of the partners swapping their roles, which happens according to the following rules:

- only one person involved in the exchange is speaking at the same time;

- two or more people speaking simultaneously happens for a short time and only when the other partner is taking their turn;

- the turn-taking period is short and distinguished by the withdrawal of the first partner and a simultaneous full involvement of the second one;

- a longer silence is a signal of interference, and means that the listener does not want to or cannot take over the role of the speaker; it is also associated with some discomfort for the communication partners;

- further turns may be limited to one word, one sentence or contain longer narrative monologues;

- each participant of the communication process is responsible for organizing their turn so the listeners have a possibility of ending it and the transition is as smooth as possible.

By taking turns, participants of the communication process create adjacency pairs, with each such pair consisting of elements which are:

[1] semantically linked; the first part of the pair - created by the first conversation partner, elicits a specific second part - expressed by the other partner,

[2] presented in a strict order: „the first part" - „the second part”,

[3] culturally normalized so that a specific first part requires the use of a specific second part. e.g. a question generates an answer. If a partner cannot add a matching part, they are required to explain why,

[4] implemented in such a way that when one of the conversation partners presents a first part of a pair, the second person is required to immediately introduce the second part of the same pair. (Nęcki, 2000: 140)

The purpose of communication (in a relation with a partner) is to understand the mutual intentions of the participants of the communication process. 
Both the speaker's proceedings and the recipient's response are not autonomous actions. There is a clearly defined relation: a communication partner is supposed to elicit a reaction of the recipient, and the reaction of the other partner as well as the way they develop the tackled topic, that is a creation of an adjacency pair, produces in turn a response from the first partner, or an alignment of another adjacency pair. This becomes possible thanks to the use of one of two possible methods to create such pairs: the chain-link method - a chain is created when an adjacency pair is followed by a second one arising from it, or by using feedback that is an overlap of two speech acts (expressed directly and indirectly). Even if the communication process assumes the form of a monologue ,it is never a pure one-way communication, because the other party manifests their emotions and thoughts, e.g. irritation, boredom, anger, fascination, etc., with the help of nonverbal signals" (Dobek-Ostrowska, 2007: 21). In such a natural communicative relation, each of the partners can initiate an interaction, respond to the partner's messages (referring to pragmatic acts adequate in a given situation which allow them to not only communicate individual intentions and subjective or culturally imposed meaning, but result in a real dialogue consisting of negotiating meanings and reaching an agreement) in a flexible and unconstrained way (according to the basic rules of mutual creation of the communication process), as well as successfully complete the interaction and end a turn. Perceived this way, the conversation becomes conducive to the development of broadly defined communicative skills of its partners (Kuszak, 2011a), as indicated by, among others, M. Lewartowska-Zychowicz recalling R. Kwaśnica's following thought: „This inspired Gadamer's concept of dialogue, the ability of a dialogical way of being in the world, consisting of conversation with others and with ourselves in the search for meaning. It replaces technically understood communicative competence understood as talking in a comprehensible way about the results of cognition" (Lewartowska-Zychowicz, 2009: 159). Following this line of thought, D. KlusStańska proposes to differentiate between two types of dialogue: dialogue as an exchange of opinions and dialogue as an exchange of meanings. As she says, "a dialogue of people exchanging sentences may be a monologue of meanings (...) When one party's system of meanings dominates over the exchange, when the status of meanings is asymmetrical, the result is a monologue of meanings embedded within a dialogue of people" (Klus-Stańska, 2011: 143).

\section{Communication at school as a non-dialogic form}

The peculiar character of classroom communication is a result of the institutional operational framework and the imposed rules of communication between the various participants of the interpersonal exchange process, the imbalance 
between role of the teacher and that of the student, as well as the so-called classroom and teaching conditions, which through a strictly-defined spatial arrangement channel the communication between teachers and students. However, one cannot forget that all variants of the teaching process conducted within the school space are, as J. Kowalikowa strongly emphasises, a process of communication executed through language (Kowalikowa, 2002: 12). Nevertheless, the use of language in this process is of a receptive nature, restricted not only by the highly formalized organization of today's school, but also by the lacking in reflection, stereotypical thinking about the roles of the student and the teacher which is a feature of the highly ritualised functioning of these two entities, where the latter is often still considered more of a message recipient rather than a dialogue partner.

\section{Communication at school as a formalised communication}

As an institution where interpersonal relations adopt a formal nature, school requires both teachers and students to use a specific language, determined by the so-called obligation of „school politeness”, which can be described as follows:

- Participation in the communication process is obligatory; the requirement that the formal presence of the student during class be recorded in the class register makes school communication compulsory;

- Initiating communication often happens in the form of calling/reading the student's name and assigning / imposing a subject which the student should elaborate upon;

- Speaking up / undertaking an activity requires the student to ask for teacher's permission and obtain his/her consent;

- The conversation resembles a screenplay because "most of the utterances are completed, most speakers seem to know their role and recognize their turn to speak. Despite their large number, these utterances seem very well organized." (Cohen, Manion, Morrison, 1990: 258);

- Students must present their utterances in the form of full sentences according to the rule: „at school we speak in full sentences”;

- Students' utterances should be properly constructed, according to the rule: "at school we do not start a sentence with so", which brings students' and teachers' attention to the form of the utterance, not its content;

- Students' utterances should be completed in a specific amount of time, according to the arrangements: "who has a question?, "Now is not the time to ask questions"; 
- The teacher decides when the topic of the discussion is exhausted and how long the discussion should last, the formal indication of the timeframe of communication is the beginning and end of classes (lessons).

The organization of the classroom space and enclosing the communication within the framework of a lesson determines "the monotony of social situations where students undertake communication" (Klus-Stańska, 2005: 95). A strictly defined arrangement of desks with the teacher as the focal point channels students' communicative activity along the student-teacher axis, thus making the communication vertical and public, as well as requiring the attention of all present for every utterance. In such a situation, ,it is difficult for the teacher to avoid talking down to students" (Cohen, Manion, Morrison, 1990: 260). To contribute to the smooth functioning of communication, students "should demonstrate efficiency in making and continuing conversation according to the teacher's intentions" (Nowicka, 1999: 23).

\section{Communication at school in the context of the asymmetry of teacher's and students' rights and privileges}

Describing the relationships at school, J. Bałachowicz says that "due to his/her functions and role, it is the teacher who to a large extent co-creates the context of child's development, at the same time himself/herself being an element of this context" (Bałachowicz, 2008: 72). The rights of teacher and student at school and in the classroom are asymmetrical, with the teacher's position clearly being privileged compared to students. Developing this thesis and describing the disparities between the roles of teacher and student in the process of co-creating communication, I will highlight the following elements constructing the communicative relationship at school:

[1] "The teacher is the central figure, he/she is the main sender, the primary recipient and manager of the rules of communication" (Nowicka, 2000: 46). The privilege of formulating longer utterances and selecting a topic is reserved to him/her, students are required to express statements about the issues he/she imposed and speak briefly referring to the topic at hand. In this situation, students quickly learn that "nobody is interested in what they really think" (Klus-Stańska, Nowicka, 2005: 104). Thus, they learn to express utterances which will meet the teacher's expectations, both in terms of content and form. As a result, the communication process in which students participate happens without their involvement because "the content is relatively unimportant in the sense that meanings are determined without the student's involvement" (Klus-Stańska, 2005: 109). 
[2] Communication is dominated by the teacher's monologue and student's activity is reduced to passive listening. This issue is described by M. Śnieżyński as follows: „this type of contact at school is mostly of a one-way nature (the teacher speaks - the student listens). As a result, the teacher's influence is limited and restricted mainly to the receptive sphere" (Śnieżyński, 2011: 59). J. Bałachowicz also underlines that the dominant form of school communication education is a lecture held by the teacher, which „is of a reproductive and instructional nature, and does not fulfil any developmental function in the area of communicative and personal competence" (Bałachowicz, 2009: 231).

[3] A sign of the asymmetry of school roles is also the imbalance in the number and form of the questions posed during lessons by the teacher and students. Teachers ask students various questions, but they rarely consider the meaning of posing questions to students. It should be noted that a large part of the questions which teachers address to students pertain to: checking their knowledge, focusing on the task at hand, consolidating knowledge, organizational matters (Cohen, Manion, Morrison, 1990: 268). On the other hand, students are allowed to ask questions related almost exclusively to organizational issues, such as: „Should we write this down in our notebooks?”, "What colour should we use to underline this?”, „Can I write it down with a pen?”. Consequently, „children's natural tendency to pose questions, stemming from their intellectual growth and cognitive needs, is not employed and developed during class, on the contrary, it is often inhibited. Students' cognitive needs and interests are effectively suppressed by the teacher and his/her domination, particularly when it comes to teaching communication" (Michalak, 2004: 101).

[4] Another aspect of the communicative asymmetry of teachers' and students' roles, is the imbalance in the ability to express directive and controlling messages, which W. Łukaszewski describes as follows: ,in a more or less categorical form, they advise the recipient to perform some actions or to refrain from them" (Łukaszewski, 1996: 219). In school relations, only the teacher has the privilege of addressing students with messages such as „,come to the blackboard”, „read what you wrote”, „write neatly”. Describing the specifics of the relationship between the participants of the classroom communication process, M. Nowicka developed the following list of directive messages which teachers address to students:

- micromanaging - giving detailed instructions,

- enlightening - imposing ways of thinking and perceiving reality,

- drilling - constant disciplining,

- legitimising an externally imposed authority figure - a cult of the teacher, 
- distancing - formalising relationships,

- taming - masking and bolstering authority with an atmosphere of kindness,

- increasing dependence - strengthening children's connection to the authority figure,

- retarding - limiting independence (Nowicka, 2010: 164).

F. Janssen-Vos summarized school communication in a very apt way, noting that "teachers too often attach too much importance to their own plans and reasoning. They wait for the „correct" answers and help to find them. However, conversations conducive to development should spring first and foremost from the child's reasoning and utterances" (Janssen-Vos, 2009: 235).

[5] The teacher's privileges also include the control over sound and silence during class. The teacher decides when students can speak, what intensity of sound is acceptable in a given situation, but also "suppresses unwanted sounds during class which students make: shouts, laughter, talks among the students (...). The teacher restricts the natural sounds distinctive of the child's world" (Nowicka, 2011:266).

On the other hand, practically the sole expectation made of students is that they effectively communicate declarative messages which conform to the teacher's expectations both in terms of content and form. It should be noted that there are many informative messages among teachers' utterances addressed to students; nevertheless, a large part of them are the so-called pseudo-declarative messages, which W. Łukaszewski describes as "a covert form of a controlling message” (Eukaszewski, 1996: 220). As the same author further shows, „pseudo-declarative messages consist in part of intentional - and quite sophisticated - techniques of controlling someone else's behaviour" (Łukaszewski, 1996: 220). While recognizing the teacher-student communication as dominated by controlling messages, it should also be acknowledged that it is to a large extent a form of communication largely dominated and controlled by the teacher. However, it should be emphasized, as A. Janowski does, that verbal contacts between the teacher and individual students are not only highly formalized but also very much varied. Teachers initiate relationships with some students more frequently, while ignoring others, which significantly differentiates the communicative experience of students.

\section{Communication at school as a ritual activity participated in by teachers and students}

Communication in the school space occurs in accordance with established rituals of teacher-student relationships understood as „sets of action which constitute the external form of a ritual" 'Drabik, Kubiak-Sokół, Sobol, Wiśniakowska, 2011: 
881) and „verbal formulas, to which the law, tradition and custom give meaning of a symbol" (Ogrodowska, 2001: 189). A characteristic feature of the ritual is to perform specific actions in an order which has been strictly defined in advance. According to Z. Mach, a ritual "through the ideological and at the same time emotional power of its symbolic message has the ability to organize human thoughts and feelings" (Mach, 2005: 35). The overt structure of a ritual consists of the following elements:

- The leader-the teacher - responsible for the course of school rituals, his/her task is to "ritualise the space and objects (people) according to the meanings of a given ritual" (Dembiński, 2005: 52). The ritual is executed through both specific gestures and actions as well as uttered words;

- The group - students, who contribute to the creation of a ritual and adopt highly specific roles (class president, person responsible for cleanliness in the classroom) throughout it; the actions they undertake together within the framework of a given ritual bring the group closer together;

- Gestures, directly related to the content and course of the ritual. Each utterance requires students to raise their hands and indicate they would like to speak, while the teacher allows them to speak by pointing at them with his/her hand or nodding his/her head. When students end their utterance, it also results in the teacher's acceptance or lack of it, expressed in a nonverbal way (nod/head gesture showing a lack of approval for the content or form of the student's utterance);

- Objects which „through ritual actions gain particular meanings” (Dembiński, 2005: 53). These include a class register (regardless whether in the traditional or online form), student's record book, previously chalk, which is recently being replaced with computers, tablets or interactive whiteboard. Those and other ritual objects play key roles in the course of the ritual, in this case the role of an instrument/channel in the communication process between the participants of the ritual;

- Space/place of the ritual action, that is the classroom, made up of its unique equipment and items which receive ritual meanings, such as the teacher's table/desk - the splace for the leader of the ritual communication, students' desks - as the place of action and communication largely centred on the teacher, carpet - as the place for decentred action and communication. As A. Janowski points out, ,the objects in various classrooms are usually very similar when it comes to function; there is always a litter bin, pencil sharpeners for general use, sometimes a bulletin boards, almost always decorations of some sort (...) The decorations in rooms dedicated to children starting their school education usually com in a distinctive style - toys, cut-outs, colours, it all a little resembles kindergarten and is supposed to 
ease the young child's transition from the "patient» home world into the difficult school world" (Janowski, 1995: 47). The issue of the unification of school space is also discussed by M. Nowicka, pointing out that "classrooms are usually very similar to one another. There is furniture of the same type, located similarly throughout the room" (Nowicka, 2011: 252). Unification makes it easier to implement the school ritual. As M. Nowicka further states, the physical space of a classroom is fully open to the teacher, and he/she has many places there reserved only for him/herself. The student's space, on the other hand, is cramped and restricted, perpetually prone to the teacher's invasion (Nowicka, 2011:252);

- Time - during ritual actions it is strictly specified, contained within a timeframe signified e.g. by the sound of a school bell. The timeframe of a ritual is also divided into regularly repeating slots, e.g. time for the roll call, time to check homework, time to do a new task etc.;

- Speech - a linguistic ritual distinguished by the fact that every participant of the communication process knows exactly what to say, and teachers expect the students to speak up. Speech plays a key role in the implementation of a ritual.

A. Engelking discerns between the following verbal rituals:

- rituals of creation (conjuring) - an individual (a group) wants something to happen,

- rituals of protection - an individual (a group) wants something not to happen (avoidance and prevention ritual),

- rituals of removal - an individual (a group) wants something to „un-happen”,

- rituals of preservation - an individual (a group) wants something to last (after Dembiński, 2005: 92).

According to A. Janowski, each school and class group features a particular ritual as well as permanent actions which in essence do not differ from each other. „It all happens in a world governed by the rules known to teachers and students. Due to this, the teacher can use abbreviated forms, such as: «too loud», «hands, please», without worrying he or she won't be understood" (Janowski, 1995: 55).

\section{Communication at school as a "monologue of meanings" according to the script included in a textbook}

D. Klus-Stańska, describing the monologue of meanings between the teacher and students, points to the asymmetry of power and meanings, domination of one party in the dialogue, domination of one of the party's meanings, emotional 
openness of only the dominating side, patronising permission, "paternalistic” or „maternal” ideology (Klus-Stańska, 2011: 145). According to this author, the dominance of power over meanings in the school space boils down to the fact that "the status of the one who knows is clearly indicated, and the questions that this person asks the others belong to a set whose answers he/she knows in advance. "The basic tool of knowledge transmission and legitimization of the undisputed position of teacher in communicative relationship with the students is the textbook, whose content the teacher reveals to students in a systematic and gradual way. The textbook „organizes knowledge according to a clearly outlined timeline of learning progress, provides unambiguous criteria, removes uncertainty and hidden hierarchies" (Bernstein, 1990: 104). Communication at school is focused on content related to the socio-cultural reality, tradition and history, which is provided to children through the textbook. Thus, not only is content previously unavailable to students distributed during class (Zalewska, 2009: 525), but it is also interpreted in a specific way. These interpretations, as E. Zamojska points out, are offered from two points of view:

- from the perspective of adult and mature people, they take on the form of personal memories - „these are mostly sentimentally coloured descriptions of the «land of childhood» which they lost due to age" (Zamojska, 2011: 147),

- from the perspective of adults, but clearly aimed at children. „The intention behind them (...) may be the willingness to exert a greater or lesser influence over the development, but it may also be the willingness to help, understand, show empathy and support in solving problems" (Zamojska, 2011: 147).

It is rare to present reality from the perspective of children themselves. No space is left for student's personal interpretations. The information on "the position students have compared to others when it comes to their learning progress is also provided selectively. It is, therefore, a silent medium which creates conditions conducive for competition" (Bernstein, 1990: 104). Through the language of textbooks, it is possible to control and shape students' language. The choice of a book and its content not only makes it possible to control the process of school communication, but allows channelling it so as to facilitate discussing specific desired - topics and avoiding the unwanted ones. The content of school books show students what is vital and which issues should be deemed less important or not important at all and should be left out of school conversations. In this way, students become objects of ideological manipulation, which through the language of the textbook shapes their beliefs, convictions, attitude towards the world, etc. It is difficult to initiate a dialogue with the book and disagree with the theses and viewpoints included there. It is also possible (and done by some 
teachers) to pretend to discuss some subjects present in the textbook with the aim of persuading students to adopt one strictly specified point of view. It should be therefore clearly stated that the control over language [exerted via a textbook annotation by K.K.] is always to an extent mind control, making school the most important subject of integration and standardisation of societies (Nowak, 2008: 29). In light of this, it is alarming that teachers cannot imagine their relations with students without a textbook as a mediator, pointing out that „a textbook is essential as the main source of knowledge and information about the world" (Drost, 2007: 129). The research carried out by M. Drost shows that over 63\% of the teachers cannot imagine classes without a textbook. When selecting one, their main criteria are: accessibility of content and graphic design (Drost, 2007: 131). It should be noted that it is the teacher who decides if the content is accessible; the child's perspective is completely omitted.

At this point, one may be justified to draw the conclusion that ,the key communicative competency acquired at school is (...) the ability to deal with a situation of control and all it entails" (Graszewicz, 2005: 72). Not only is the student not a partner in the communicative relation with the teacher, he or she is often treated as an unthinking machine programmed to perform a specific type of tasks (e.g. solving exam tests in an effective manner) and unthinkingly accept whatever the teacher selected for him/her. This statement seems to perfectly reflect the features of communicative relations where instead of mutually creating a dialogue between partners, relations of the type "we, the teachers, holding power over the communication process" and "they, the students, submissive, passive, listening to our messages, implementing our instructions" are built and strengthened.

\section{Towards a multi-subject dialogue - a chance to develop students' communicative competencies}

In the highly formalized system of school education, which imposes on its participants asymmetry of roles and channels communication around educational tasks, an opportunity for the development of students' communicative competency may be seen in the practical implementation of the concept of subjectivity in the teacher-student and student-student. relationships. In psychology and pedagogics rooted in the cognitive approach, an individual is defined as an independent creative subject "capable of shaping himself and his external environment." J. Bałachowicz underlines that ,the adoption of a model of subjective human existence and development in the world fundamentally changes the un- 
derstanding of the entire education system. The category of subjectivity determines the scope of meaning and quality of all components of the educational system, changes the view and construction of practical educational activities of the teacher" (Bałachowicz, 2007: 36-37). It is a relation where instead of functioning separately alongside each other, the participating subjects implement together ,a cooperative model of communication” (za Olczak, 2011: 125). Multisubject communication is a cognitive action which allows all its participants to experience the feeling of empowerment, the impact of verbal messages and the importance of one's own words.

In this approach, the basis of communication is dialogue, which is the "preferred method of acquisition of meaning" (Nowicka, 2009: 289). The dialogical communication model promotes student activity and increases the effectiveness of the educational process. Subject relations are open, two-directional, and aimed at respecting different needs that students can easily communicate to the teacher and other students. They can also easily act as both message recipient and sender, explain their behaviour, choices and preferences, negotiate common or individual solutions. During such non-judgemental relations, the individual learns responsibility for the communication process and genuinely develops communicative skills. „It is undisputed that to have communicative skills and use them in a constructive way, one must be provided adequate patterns, attitudes and modes of behaviour already as a child" (Kondracka, 2009: 290). Communicative situations should be performed while ensuring all subjects experience a basic sense of safety, which guarantees acceptance of both the individual student and teacher. The multi-subject communication maintains the balance between people in different aspects of verbal exchange, which is expressed through:

[1] All participants' right to respect for their beliefs and opinions, which „students deserve because they are students, and teachers deserve because they are teachers. It is this mutually experienced and expressed respect which in a way equals both subjects and justifies calling them partners despite the clear asymmetry of the relationship they are in" (Kowalikowa, 2009: 249).

[2] All participants' right to be listened to - attentive listening makes it possible to understand the essence of messages, understand other people better, establish closer relations with them, and encourages to express one's own thoughts. „When one listens to somebody attentively, one proves that one treats one's interlocutor and their experiences seriously, and respects what they have to say" (Petrie, 2011: 41).

[3] All participants' right to express their opinions, beliefs and needs verbally - provided the rules of good communication and honesty are observed, 
which is reflected in the fact that students cannot be punished in any way for displaying honesty. Their honest and authentic messages should make the teacher reflect and may lead him to offer counterarguments as an addition to the discussion. Nevertheless, they should be worded not as a reproach, but messages aimed at expanding comprehension and knowledge and in the end leading to an understanding which should be accepted by all partners.

[4] All participants' right to express their lack of agreement to beliefs, behaviours or actions of a partner, which creates a space for discussion described by J. Bałachowicz in the following way: „discussion makes it necessary to acknowledge children's competency to fully participate in this form of social communication" (Bałachowicz, 2009: 238). Therefore, it includes permission for presenting beliefs, thoughts and opinions other than those assumed by the teacher or expressed by other students. The clash of one's own beliefs and ideas with different opinions and concepts of peers and adults is and should be a vital experience for children, which allows them to learn how to cope with a conflicting situation so as not to escalate the conflict. They have an opportunity find out, in a safe situation and accompanied with an attentive and kind adult, that "most conflicts are actually communication problems” (Folger, Poole, 2009: 468). They can also, with the support of a teacher, attempt to solve the conflict and reach an understanding, which is, however, not the same as a compromise. Rather, it is, as R.B. Adler, L.B. Rosenfeld and R.F, Proctor stress, a „win-win” situation (Adler, Rosenfeld, Proctor, 2007: 398-399).

[5] All participants' right to freely take turns and elaborate on or close the topic they took over, filling it with content which the student wants to (not has to) convey, which is linked to the feeling of subjectivity and empowerment, and is a result of the right to be heard.

[6] All participants' right to receive feedback, which should be expressed in a positive way, even if it carries content which is "unwanted" by the partner, uncomfortable or difficult for him/her. Feedback makes it possible to express a message which is clear for the partner and word one's thoughts in a way which allows to understand a particular point of view.

Finally, it is worth noting that the teacher in a two-subject relation should be aware of the fact that students at the beginning and during the course of their education , are often imprecise in their utterances, talk too much or too little, are afraid of expressing their thoughts in the presence of adults, talk or not very clearly. Nevertheless, it depends on the teacher how they are going to express their thoughts, desires, needs and ideas in the future" (Kuszak, 2011b: 171). 


\section{References}

Adler R.B., Rosenfeld L.,B., Russell F. (2007). Proctor, Relacje interpersonalne. Proces porozumiewania się. Poznań.

Bałachowicz J. (2007). Podmiotowość dziecka w procesie edukacji początkowej - problemy teoretyczne i praktyczne. [W:] H. Siwek (red.). Efektywność kształcenia zintegrowanego. Inspiracje dla teorii i praktyki. Katowice.

Bałachowicz J. (2008). Styl pracy nauczyciela klas początkowych a wsparcie rozwoju podmiotowego dziecka. [W:] W. Puślecki (red.). Wspieranie rozwoju dzieci w procesie wczesnej edukacji. Wrocław.

Bałachowicz J. (2009). Style działań edukacyjnych nauczycieli klas początkowych. Między uprzedmiotowieniem a podmiotowościa. Warszawa.

Bernstein B. (1990). Odtwarzanie kultury. Warszawa.

Cohen L., Manion L., Morrison K. (1990). Wprowadzenie do nauczania. Poznań.

Dobek-Ostrowska B. (2007). Podstawy komunikowania społecznego. Wrocław.

Drabik L., Kubiak-Sokół A., Sobol E., Wiśniakowska L. (2011). Słownik języka polskiego. Warszawa.

Drost M. (2007). Podręcznik kształcenia wczesnoszkolnego w teorii i praktyce edukacyjnej. [W:] H. Siwek (red.). Efektywność kształcenia zintegrowanego. Implikacje dla teorii i praktyki. Katowice.

Folger J.P., Poole M.S. (2009). Konflikt i interakcje. [W:] J. Stewart. Mosty zamiast murów. Podręcznik komunikacji interpersonalnej. Warszawa.

Graszewicz M., Lewiński D. (2005). Kompetencja komunikacyjna a edukacja. [W:] B. Sierocka (red.). Aspekty kompetencji komunikacyjnej. Wrocław.

Klus-Stańska D. (2005). Przerywanie szkolnego monologu znaczeń. [W:] T. Bauman (red.). Uczenie się jako przedsięwzięcie na całe życie. Kraków.

Klus-Stańska D. (2011). Między przedszkolem a szkoła: od monologu do dialogu osób i znaczeń. [W:] D. Waloszek (red.). Przestrzeń i czas dialogu w edukacji. „Bliżej Przedszkola”. Kraków.

Klus-Stańska D., Nowicka M. (2005). Sensy i bezsensy edukacji wczesnoszkolnej. Warszawa.

Kondracka M. (2009). Komunikacja międzyludzka na płaszczyźnie dorosły-dziecko w przedszkolu. [W:] M. Baryluk, M. Wawrzak-Chodaczek (red.). Wartości komunikacji różnych grup społecznych. Toruń.

Kowalikowa J. (2002). System i komunikacja w kształceniu językowym i w edukacji lingwistycznej nauczycieli. [W:] M.T. Michalewska, M. Kisiel (red.). Problemy edukacji lingwistycznej. Ksztatcenie języka ojczystego dziecka. Kraków.

Kuszak K. (2011a). Kompetencje komunikacyjne dzieci w okresie późnego dzieciństwa $w$ aspekcie rozwojowym. Poznań.

Kuszak K. (2011b). Relacja komunikacyjna dziecka sześcioletniego z dorostym interlokutorem. [W:] A. Tyl (red.). Nauczyciel wczesnej edukacji wobec zmieniajacej się rzeczywistości edukacyjnej, kulturowej i społecznej. Łódź.

Lewartowska-Zychowicz M. (2009). Nauczyciel (wczesnej edukacji) w relacjach wolności i przymusu. [W:] D. Klus-Stańska, M. Szczepska-Pustkowska (red.). Pedagogika wczesnoszkolna - dyskursy, problemy, rozwiazania. Warszawa.

Łukaszewski W. (1996). Człowiek i kultura. [W:] T. Jaworska, R. Leppert (red.). Wprowadzenie do pedagogiki. Wybór tekstów. Kraków. 
Nęcki Z. (2000). Komunikacja międzyludzka. Kraków.

Nowak Z. (2008). Szkoła jako fabryka (szkic o standaryzacji ludzi i kultury). [W:] B. Muchacka, M. Szymański (red.). Szkoła w świecie współczesnym. Kraków.

Nowicka M. (2000). Sprawność komunikacyjna dzieci w interakcjach szkolnych. Olsztyn.

Nowicka M. (2009). Oblicza szkolnej socjalizacji. [W:] D. Klus-Stańska, M. Szczepska-Pustkowska (red.). Pedagogika wczesnoszkolna -dyskursy, problemy, rozwiązania. Warszawa.

Nowicka M. (2010). Socjalizacja na lekcjach w klasach początkowych. Praktyki - przestrzenie konceptualizacje. Toruń.

Nowicka M. (2011). Przestrzeń fizyczna klasy szkolnej jako środowisko socjalizacji dziecka. [W:] D. Klus-Stańska, D. Bronk, A. Malenda (red.). Pedagogika wczesnej edukacji. Dyskursy, problemy, otwarcia. Warszawa.

Ogrodowska B. (2001). Zwyczaje, obrzędy i tradycje w Polsce. Warszawa.

Olczak A. (2011). Dialog w diadzie dziecko - dorosty. [W:] D. Waloszek (red.). Przestrzeń i czas dialogu w edukacji. „Bliżej Przedszkola”. Kraków.

Petrie P. (2011). Komunikacja w pracy z dziećmi i młodzieżą. Wprowadzenie do pedagogiki społecznej. Poznań.

Śnieżyński M. (2011). Demokracja - dialog - edukacja. Trud budowania i rozwijania dialogu edukacyjnego. [W:] D. Waloszek (red.). Przestrzeń i czas dialogu w edukacji. „Bliżej Przedszkola”. Kraków.

Zalewska E. (2009). Programy kształcenia i podręczniki szkolne w edukacji początkowej jako „wybór $z$ kultury". [W:] D. Klus-Stańska, M. Szczepska-Pustkowska (red.). Pedagogika wczesnoszkolna - dyskursy, problemy, rozwiazania. Kraków.

Zamojska E. (2011). Dzieci - dorośli. Obraz relacji w podręcznikach szkolnych. [W:] A. Cybal-Michalska, D. Kopeć, W. Segiet (red.). Studia z pedagogiki i nauk pogranicza. Poznań.

Zawisza-Masłyk E. (2009). Kształtowanie kompetencji komunikacyjnych u gimnazjalistów - zapomniany obszar. [W:] M. Baryluk, M. Wawrzak-Chodaczek (red.). Wartości komunikacji różnych grup społecznych. Torun. 
